\title{
Stabilnost vlada i upravljanje koalicijskim sukobima u Hivatskoj
}

\author{
Dario Nikić Čakar*

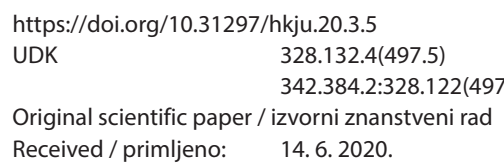

Cilj je rada istražiti stabilnost koalicijskih vlada u Hrvatskoj 2000. - 2020. te se polazi od teze da je nestabilnost vlada uvjetovana nedovoljno obuhvatnim koalicijskim sporazumima i neučinkovitim mehanizmima rješavanja koalicijskih sukoba. U radu se prvo analiziraju koalicijski sporazumi s obzirom na veličinu i sadržaj koji je u njima zastupljen, a zatim se istražuju stvarni procesi koalicijskog upravljanja koji se događaju unutar „crne kutije“ identificiranjem najčešćih sukoba i mehanizama s pomoću kojih se oni nastoje riješiti. $U$ analizi se upotrebljavaju izvorni empirijski podaci prikupljeni intervjuima s bivšim članovima koalicijskih vlada, kao i koalicijski sporazumi, vladini programi, arhivska građa dviju dnevnih novina te arhivske baze vlade i parlamenta. Rezultati istraživanja doveli su do glavnog zaključka da zbog nedovoljno razrađenih i formaliziranih koalicijskih

* Doc. dr. sc. Dario Nikić Čakar, Fakultet političkih znanosti, Sveučilište u Zagrebu, Hrvatska (Assistant Professor, Faculty of Political Science, University of Zagreb, Croatia, e-mail: dario.nikic@fpzg.hr)

ORCID ID: https://orcid.org/0000-0001-9905-8066 
sporazuma koalicijske stranke nisu uspješne u upravljanju koalicijskim sukobima, stoga pribjegavaju ad boc mehanizmu neformalnog i vrlo personaliziranog odlučivanja koje se izgrađuje u malom gremiju čelnika koalicijskih stranaka.

Ključne riječi: stabilnost koalicijskih vlada, koalicijski sporazumi, međustranački sukobi, koalicijsko upravljanje, $\mathrm{Hr}-$ vatska

\section{Uvod}

Brojna istraživanja upućuju na to da je stabilnost vlada iznimno važna za funkcioniranje cjelokupnoga političkog sustava. Vlade su izvršna i operativna tijela koja svakodnevno donose odluke kojima utječu na živote svih građana, zbog čega njihova nesposobnost odlučivanja zbog strukturne nestabilnosti i kratka trajanja može dovesti do nezadovoljstva među građanima i niske razine povjerenja u političke institucije i demokratski politički poredak u cjelini. Krauss (2018, str. 1283) upozorava da „niže razine trajnosti kabineta mogu imati za posljedicu ne samo slabija postignuća vlada, nego isto tako mogu u konačnici ugroziti postojanje političkog sustava."

U literaturi iz koalicijskih studija (coalition studies) postoji suglasje o tome da je najbolja mjera stabilnosti vlada duljina njihova trajanja, odnosno empirijsko razdoblje između formiranja vlade i okončanja njezina mandata. Konvencionalno se uvriježilo da postoje tri kriterija koja označavaju završetak mandata vlade: (1) promjena stranačkog sastava vlade, (2) održavanje parlamentarnih izbora i (3) promjena premijera (King, Alt, Burns \& Laver, 1990; Müller \& Strùm, 2000; Strùm, Müller \& Bergman, 2008). U tome je pogledu dokazano kako su u parlamentarnim demokracijama koalicijske vlade u pravilu manje stabilne od jednostranačkih jer su zbog svoje višestranačke strukture podložnije prijevremenom okončanju mandata.

Dosadašnja istraživanja stabilnosti vlada u zapadnim demokracijama izgradila su tri teorijska pristupa objašnjenju njihove stabilnosti. Atributski pristup privukao je pozornost 1970-ih stavljanjem naglaska na strukturna obilježja vlada kao atributa koji su statistički povezani s duljinom trajanja mandata: broj stranaka u vladi, većinski status vlade, ideološka kompaktnost, fragmentiranost stranačkog sustava te konstitucijska pravila koja utječu na trajanje vlade poput formalne investiture, ovlasti predsjednika države i ovlasti premijera (Laver, 1974; Warwick, 1994; Grofman \& Roozendaal, 1997; Saalfeld, 2008). Noviji događajni pristup pokazuje da kraj 
mandata vlade nije determiniran njezinim strukturnim obilježjima, nego ponajprije kritičnim događajima poput političkih skandala, međunarodnih sukoba, ekonomskih kriza i sl. (Strùm et al., 1988; Ciofi-Revilla, 1984; Saalfeld, 2008). Konačno, pristup teorije igara promatra koalicijske stranke kao racionalne aktere koji procjenjuju svoje koristi i troškove sudjelovanja u koalicijskoj vladi i na temelju tih procjena donose strateške odluke o održavanju ili okončanju koalicijske suradnje u vladi (Lupia \& Strùm, 1995; Krauss, 2018).

Dok literaturom iz koalicijskih studija uglavnom dominiraju teme vezane za formiranje i okončanje koalicijskih vlada, dotle je razmjerno malo istraživanja koja pozornost usmjeravaju na analizu interakcije između stranaka koje participiraju u vladi, odnosno na proces koji je u novijim koalicijskim studijama opisan kao koalicijsko upravljanje. Procesi i interakcije među koalicijskim partnerima u vladi mogu biti važni za njezinu stabilnost jer razlike među koalicijskim strankama mogu dovesti do nepremostivih i ozbiljnih sukoba u koaliciji koji povećavaju rizik prijevremenog okončanja mandata. U tome su pogledu neke studije pokazale važnost koalicijskih sporazuma kao kontrolnih mehanizama kojima se izbjegavaju ili razrješavaju unutarkoalicijski sukobi te se tako smanjuje rizik ranog okončanja mandata vlade (Timmermans \& Moury, 2006; Andeweg \& Timmermans, 2008; Saalfeld, 2009; Moury \& Timmermans, 2013).

Recentna istraživanja pokazala su da je iskustvo s koalicijskim vladama u novim demokracijama u srednjoj i istočnoj Europi obilježeno postojanjem formalnih koalicijskih sporazuma, ali ih se istodobno koalicijski partneri pridržavaju u puno manjoj mjeri nego oni u zapadnoj Europi (Bergman, Ilonszki \& Müller, 2019a). Osim toga, nekoliko je komparativnih studija pokazalo da su koalicijske vlade u srednjoj i istočnoj Europi znatno nestabilnije nego vlade u zapadnoj Europi s obzirom na to da vlade $u$ novim demokracijama u prosjeku traju gotovo dvostruko kraće od onih u starim demokracijama na zapadu (Bergman, Ersson \& Hellström, 2015; Bergman, Ilonszki \& Müller, 2019b; o (ne)stabilnosti vlada u regiji vidi i Grotz \& Weber, 2012; Somer-Topcu \& Williams, 2008; Nikolenyi, 2004; Blondel, Müller-Rommel \& Malova, 2007; Blondel \& Müller-Rommel, 2001; Müller-Rommel, 2005).

Budući da je Hrvatska dosad bila izuzeta iz komparativnih studija o koalicijskim vladama, osnovni je cilj ovog rada istražiti stabilnost koalicijskih vlada u Hrvatskoj od 2000. do 2020. analizirajući kakav utjecaj imaju mehanizmi rješavanja unutarkoalicijskih sukoba, definirani koalicijskim sporazumima, na stabilnost vlada i duljinu njihova mandata. Budući da 
koalicijske vlade u Hrvatskoj pokazuju slične strukturne nestabilnosti kao i vlade u drugim zemljama u regiji, postavlja se temeljno pitanje može li se ta nestabilnost, mjerena kraćim vijekom, objasniti načinima rješavanja sukoba unutar koalicija i karakteristikama koalicijskih sporazuma. Kakvi tipovi sukoba dovode do prijevremenog okončanja mandata koalicijskih vlada i kakvim sporazumnim mehanizmima stranke u koalicijama nastoje riješiti te sukobe? Osnovna je teza da je relativna nestabilnost vlada u Hrvatskoj uvjetovana nedovoljno obuhvatnim koalicijskim sporazumima kojima koalicijski partneri ne mogu nametnuti učinkovite mehanizme rješavanja koalicijskih sukoba.

\section{Koalicijsko upravljanje i mehanizmi rješavanja koalicijskih sukoba}

Koalicijske studije dugo su bile zaokupljene istraživanjem trajnosti vlada, koje je uglavnom bilo fokusirano na početnu fazu formiranja i završnu fazu svršetka mandata vlade. Međutim, ono što se događa između „rođenja“ i „smrti“ vlade, razmjerno je dugo bilo zanemareno kao istraživačka tema, djelomično zbog toga što su se vlade percipirale kao „crne kutije“ čiji je unutrašnji način rada i odlučivanja bio izvan domašaja znanstvenog interesa. ${ }^{1}$ Upravo zato novije studije o koalicijskim vladama počele su promatrati koalicijsku politiku kao cjelovit sustav koji se događa u četirima fazama - parlamentarni izbori, formiranje vlade, koalicijsko upravljanje i svršetak vlade - koje su međusobno povezane u životni ciklus koalicijske politike (Müller, Bergman \& Strùm, 2008, str. 11; Müller, Bergman \& Ilonszki, 2019b, str. 9). Važno je naglasiti da su te četiri faze međusobno isprepletene i stoga ih je vrlo teško empirijski strogo razdvojiti jer odnosi među političkim strankama i suprotstavljenost njihovih ciljeva u jednoj fazi determiniraju ishode njihova djelovanja kao ključnih aktera u sljedećim fazama.

Koalicijsko upravljanje kao jedna od faza koalicijske politike posljednjih je dvadesetak godina počelo zadobivati sve veću pozornost znanstvenika, poglavito zbog nastojanja da se steknu uvidi u to kako koalicijski partneri

${ }^{1}$ Tek su rani radovi Lavera i Shepslea početkom 1990-ih uputili na taj nedostatak u teorijama koalicija ističući da su teme poput načina vladina odlučivanja i stvaranja javnih politika jednako važne kao i pitanja formiranja koalicija i njihove trajnosti (Laver \& Shepsle, 1990; 1996). 
surađuju i stvaraju politike od trenutka kad se vlada formira. Međutim, Müller, Bergman i Ilonszki upozoravaju na to da je upravo ta višestranačka struktura koalicijskih vlada jedan od glavnih uzroka njihove strukturne nestabilnosti. „Glavni građevni blokovi koalicijskih vlada, političke stranke, imaju različite, a često i djelomično suprotstavljene policy preferencije. One isto tako mogu iskazivati interes za iste pozicije i resore kao i njihovi partneri. I ono najvažnije, na idućim će se izborima kandidirati svaka za sebe, također se natječući s ostalim koalicijskim strankama." (Müller, Bergman \& Ilonszki, 2019, str. 11). Iz toga jasno proizlazi da se koalicijski partneri nalaze u svojevrsnom sukobu interesa koji vrlo često može dovesti do programskih i kadrovskih konflikata kojima se može ugroziti stabilnost vlade i posljedično izazvati njezin pad.

Unutar koalicijskih vlada sukobi se mogu pojaviti između individualnih ministara/ministarskih resora ili koalicijskih stranaka, stoga se u prijašnjim studijama napravila podjela na međuresorne i međustranačke sukobe (Andeweg \& Timmermans, 2008). ${ }^{2}$ Iako razlikovanje tih dviju vrsta sukoba nije potpuno isključivo jer međuresorni sukobi mogu u nekom trenutku prerasti u međustranačke, valja naglasiti da međustranački sukobi puno više ugrožavaju stabilnost vlada i češće mogu dovesti do prijevremenog okončanja mandata. Odnosi među strankama u koaliciji mogu biti narušeni sukobima oko politika (policy conflicts) kad koalicijski partneri imaju različite ciljeve i preferencije u provođenju politika ili sukobima oko osoblja (personnel conflicts) koji nastaju u vezi s izborom ili imenovanjem neke osobe na dužnost u vladi. S obzirom na to da su međustranački sukobi najčešći uzrok prestanka koalicijske suradnje i završetka mandata vlade (Müller \& Strùm, 2000; Damgaard, 2008), koalicijski partneri moraju pronaći mehanizme zajedničke suradnje izbjegavanjem i učinkovitim rješavanjem sukoba kako bi preživjeli na vlasti.

Na koji način koalicijski sporazumi utječu na očuvanje stabilnosti koalicijskih vlada? Koalicijski sporazumi smatraju se ex ante mehanizmima koordinacije kojima koalicijske stranke nastoje ostvariti svoje programske ciljeve i zaštititi se od rizika koji proizlaze iz međusobnih sukoba. Oni su

${ }^{2}$ Neki su autori istraživali i unutarstranačku politiku koalicijskih partnera kao potencijalni izvor koalicijskih sukoba (Saalfeld, 2009). U osnovi je riječ o tome da sukobi između različitih razina stranačke organizacije ili pojedinaca unutar stranke mogu ugroziti opstojnost koalicijske vlade. Problemi proizišli iz kolektivnoga stranačkog nezadovoljstva podjelom ministarskih resora među koalicijskim partnerima, neispunjenih osobnih ambicija pojedinih stranačkih dužnosnika ili kompromisa koje stranka treba postići s koalicijskim partnerima o programskim ciljevima vlade katkad mogu dovesti do sukoba unutar stranke koji se u najgorem slučaju mogu okončati rušenjem pojedinih ministara ili cijele vlade. 
„najobvezujući pisani iskazi kojima se stranke koalicije međusobno obvezuju, odnosno, to je najautoritativniji dokument koji ograničava ponašanje stranaka" (Müller \& Strùm, 2008, str. 170). S jedne strane, koalicijski sporazumi služe kao najvažniji mehanizam prevencije i izbjegavanja konflikata jer identificiraju i otklanjaju potencijalne točke prijepora i osjetljive teme među koalicijskim partnerima prije nego što stranke udružene u koaliciju preuzmu vlast. S druge strane, koalicijski sporazumi služe i kao ex post mehanizmi rješavanja potencijalnih nepredvidivih sukoba koji se mogu pojaviti tijekom mandata jer su njima definirana i proceduralna pravila s pomoću kojih koalicijske stranke mogu lakše upravljati konfliktnim situacijama kad se pojave. Neka su istraživanja pokazala da samo postojanje koalicijskog sporazuma, kao i njegova obuhvatnost/duljina, smanjuju rizik od pojave međustranačkih koalicijskih sukoba i prijevremenog okončanja mandata vlade (Krauss, 2018). Upravo zbog te važnosti koju mehanizmi prevencije i rješavanja sukoba imaju za održavanje stabilnosti vlada, oni se mogu smatrati najvažnijim alatom koalicijskog upravljanja.

Strùm i Müller (1999) te Müller i Strùm (2000; 2008) u svojim empirijskim studijama o koalicijskim ugovorima pokazali su da postoje tri glavna tematska područja uobičajeno zastupljena u dogovorima koalicijskih partnera: sporazum o javnim politikama, raspodjela resora i proceduralna pravila. Oni su postavili i indikatore koji mjere duljinu sporazuma, udio pojedinih tematskih područja i stupanj formaliziranosti sklopljenih sporazuma. Dosadašnja komparativna istraživanja uglavnom su se fokusirala na policy aspekt koalicijskih sporazuma i pokazala su da je u većini zapadnih demokracija više od 90 posto sadržaja koalicijskih sporazuma posvećeno javnim politikama (Müller \& Strùm, 2008). Ponešto usredotočenije studije s manjim brojem slučajeva pokazale su da koalicijske vlade tijekom mandata realiziraju većinu policy ciljeva koji su definirani koalicijskim sporazumima, kao i da detaljni i obuhvatni koalicijski sporazumi pomažu ograničiti ministre i stranke u tome da samoinicijativno mijenjaju dogovorene politike (Timmermans, 2006; Moury, 2013; Moury \& Timmermans, 2013; Indridason \& Kristinsson, 2013; Bowler et al., 2016). ${ }^{3}$ Jedna recentna studija koalicijskih vlada u Sloveniji pokazala je da njihovim koalicijskim sporazumima dominiraju sadržaji javnih politika, ali da se u

${ }^{3}$ Tako su, primjerice, Bowler i dr. (2016) u svome istraživanju koalicijskih vlada na razini njemačkih saveznih pokrajina zaključili da ideološka kompozicija koalicija i veličina koalicijskih stranaka imaju znatan utjecaj na veličinu koalicijskih sporazuma. Preciznije rečeno, ideološki heterogenije koalicije koje imaju veći potencijal međustranačkog sukoba sklonije su sklapati kraće koalicijske sporazume, ali isto tako puno više pribjegavaju prihvaćanju procedura za rješavanje sukoba. 
posljednje vrijeme sve veći naglasak stavlja i na proceduralne mehanizme prevencije i rješavanja sukoba (Krašovec \& Krpič, 2019). S druge strane, Müller i Strùm pokazali su da se tek u malom broju zemalja formalni koalicijski sporazumi bave pitanjem raspodjele resora i funkcija u vladi, premda autori upozoravaju da dogovori među strankama o "raspodjeli plijena“ često nisu formalni ni javno obznanjeni, stoga bi trebalo pretpostaviti da su puno češći nego što to pokazuje analiza formalnih koalicijskih sporazuma (Müller \& Strùm, 2008, str. 174).

Treće područje obuhvaćeno koalicijskim sporazumima odnosi se na proceduralna pravila koja služe kao dodatan instrument stabilizacije koalicijskih vlada. Tu je u osnovi riječ o različitim mehanizmima rješavanja sukoba i tijelima zaduženima za koordinaciju koalicijskih stranaka te upravljanje i rješavanje sukoba među koalicijskim partnerima. Bowler i dr. (2016, str. 1265) smatraju da je „ovaj aspekt koalicijskih sporazuma zadobio premalo pažnje, iako su mehanizmi upravljanja sukobima unutar koalicija važni za učinkovito koalicijsko upravljanje i opstanak koalicija, kao i za primjenu samih koalicijskih sporazuma." Kako bi osigurali učinkovito provođenje koalicijskih sporazuma, stranke u koaliciji često pribjegavaju korištenju institucionaliziranim mehanizmima nadzora preko uloga zamjenika ministara (junior ministers) i parlamentarnih odbora, koji služe kao točke kontrole jednoga koalicijskog partnera nad drugim. S obzirom na to da se njima ne mogu rješavati međustranački sukobi koji prijete prekidom koalicijske suradnje i padom vlade, Andeweg i Timmermans (2008, str. 270-272) smatraju da je potrebno strukturirati procese upravljanja koalicijskim sukobima koji će se temeljiti na dvama kriterijima: tko je uključen kao sudionik u rješavanje sukoba i koji se mehanizmi upotrebljavaju kako bi se sukob riješio. Na temelju tih kriterija identificirali su tri arene za rješavanje koalicijskih sukoba: unutrašnja arena u kojoj postoje visokoinstitucionalizirana tijela poput užeg kabineta vlade i vladinih odbora u kojima su zastupljeni članovi vlade kao jedini legitimni sudionici; vanjska arena u kojoj postoje tijela poput odbora parlamentarnih vođa koje je institucionalizirano sa stabilnim članstvom, ali i stranački summiti koji su uglavnom ad hoc tijela koja okupljaju stranačke vođe od kojih neki mogu biti članovi vlade; miješana arena kojom dominiraju koalicijski odbori koji su u pravilu stalna tijela sa stabilnim članstvom koje čine ministri i stranački dužnosnici izvan vlade, ali i parlamentarni odbori koji kombiniraju ministre i parlamentarce. ${ }^{4}$

4 Unutrašnja arena - uži kabinet vlade / Inner cabinet (IC); vladini odbori / Cabinet committees (CaC); vanjska arena - odbor parlamentarnih vođa / Parliamentary leaders (Parl); 
Konačno, važno je istaknuti da koalicijski sporazumi ne mogu riješiti sve probleme s kojima se tijekom mandata susreću stranke okupljene u koalicijsku vladu, ponajprije jer je pisanje i sklapanje koalicijskog sporazuma bitno drukčije od njegova provođenja i pridržavanja onog što je dogovoreno. Drugim riječima, „koliko god namjere stranaka bile dobre, nema jamstva da će njihov koalicijski sporazum biti učinkovito proveden. Koalicijski su sporazumi (dramski) tekst, ali ne i predstava. Oni nam kazuju što je dogovoreno na početku koalicijskog ciklusa, ali ne i to kako se koalicijski partneri zapravo ponašaju poslije tijekom igre. Stoga, ako smo zainteresirani za stvarno koalicijsko upravljanje, ne možemo promatrati tekst kao stvarnu izvedbu." (Müller \& Strùm, 2008, str. 159). Upravo zato glavni cilj ovog rada nije samo analizirati sadržaj koalicijskih sporazuma, već ono što je puno važnije, istražiti stvarnu praksu koalicijskog upravljanja u Hrvatskoj i načine na koje koalicijski partneri upravljaju međustranačkim sukobima.

\section{Koalicijsko upravljanje u Hrvatskoj: kako stranke rješavaju sukobe unutar koalicija?}

Prije negoli se dobije uvide u obrasce koalicijskog upravljanja i mehanizme s pomoću kojih stranke u Hrvatskoj rješavaju unutarkoalicijske sukobe, potrebno je utvrditi razinu stabilnosti koalicijskih vlada u Hrvatskoj i usporediti je sa sličnim demokracijama u srednjoj i istočnoj Europi. U Tablici 1. napravljen je pregled trajanja koalicijskih vlada u Hrvatskoj u posljednjih dvadeset godina. Primjenjujući općeprihvaćene kriterije kojima se utvrđuje završetak mandata neke vlade (v. Uvod), može se zaključiti da se od početka demokratske konsolidacije 2000. na vlasti izmijenilo trinaest vlada, od kojih su samo dvije bile jednostranačke (Sanader II i Plenković II). Vlade su u prosjeku trajale 545 dana, s time da je najdulje trajala vlada Zorana Milanovića koja se održala gotovo četiri godine, a najkraće je preživjela druga vlada Andreja Plenkovića koja je funkcionirala kao jednostranačka vlada u kratkom razdoblju nakon što je HDZ okončao koalicijsku suradnju s Mostom i započeo neočekivanu suradnju s HNS-om. Premda trajanje vlada iskazano u apsolutnim brojevima može biti dobar pokazatelj stabilnosti, u tome se dobrom pokazala i mjera relativnog tra-

stranački summiti / Party summits (PS); miješana arena - koalicijski odbori / Coalition committees (CoC); parlamentarni odbori / Parliamentary committees (PC). 
janja vlada, što se računa kao omjer stvarnog trajanja i maksimalno mogućeg trajanja vlade. Prosječno je relativno trajanje vlada u Hrvatskoj 0,50, što pokazuje da je stvarno trajanje hrvatskih vlada od 2000. iznosilo samo polovicu maksimalno mogućeg trajanja, odnosno Ustavom propisanoga vremena koje je preostalo do idućih redovitih parlamentarnih izbora. ${ }^{5}$

Tablica 1. Trajanje vlada u Hrvatskoj 2000. - 2020.

\begin{tabular}{|c|c|c|c|c|c|c|c|}
\hline Vlada & 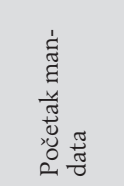 & 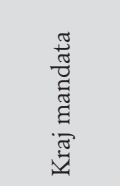 & 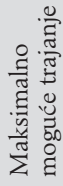 & $\begin{array}{l}\frac{0}{0} \\
\frac{\pi}{J} \\
\frac{0}{J} \\
\frac{\pi}{\pi} \\
\end{array}$ & 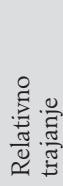 & 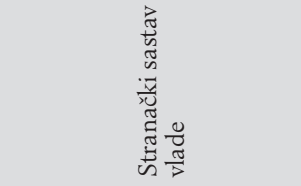 & $\begin{array}{l}\frac{0}{0} \\
\frac{\pi}{5} \\
\stackrel{0}{i}\end{array}$ \\
\hline Račan I & $27 / 01 / 2000$ & $04 / 06 / 2001$ & 1527 & 494 & 0,32 & SDP-HSLS-HNS-HSS-IDS-LS & Većinska \\
\hline Račan II & 04/06/2001 & 05/07/2002 & 1033 & 396 & 0,38 & SDP-HSLS-HNS-HSS-LS & Većinska \\
\hline Račan III & $30 / 07 / 2002$ & $23 / 11 / 2003$ & 612 & 481 & 0,79 & SDP-Libra-HNS-HSS-LS & Manjinska \\
\hline Sanader I & $23 / 12 / 2003$ & 09/02/2006 & 1520 & 779 & 0,51 & HDZ-DC & Manjinska \\
\hline Sanader II & 09/02/2006 & $25 / 11 / 2007$ & 741 & 654 & 0,88 & $\mathrm{HDZ}$ & Manjinska \\
\hline Sanader III & $13 / 01 / 2008$ & 01/07/2009 & 1519 & 535 & 0,35 & HDZ-HSS-HSLS-SDSS & $\mathrm{MPK}^{*}$ \\
\hline Kosor I & 06/07/2009 & $10 / 07 / 2010$ & 979 & 369 & 0,38 & HDZ-HSS-HSLS-SDSS & $\mathrm{MPK}^{\star}$ \\
\hline Kosor II & $10 / 07 / 2010$ & $04 / 12 / 2011$ & 610 & 512 & 0,84 & HDZ-HSS-SDSS & Manjinska \\
\hline Milanović & $23 / 12 / 2011$ & $08 / 11 / 2015$ & 1520 & 1416 & 0,93 & SDP-HNS-IDS & $\mathrm{MPK}^{*}$ \\
\hline Orešković & $22 / 01 / 2016$ & $16 / 06 / 2016$ & 1496 & 146 & 0,10 & N-HDZ-Most & Manjinska \\
\hline Plenković I & 19/10/2016 & $27 / 04 / 2017$ & 1516 & 190 & 0,13 & HDZ-Most & Manjinska \\
\hline Plenković II & $27 / 04 / 2017$ & 09/06/2017 & 1326 & 43 & 0,03 & HDZ & Manjinska \\
\hline Plenković III & 09/06/2017 & $18 / 05 / 2020$ & 1283 & 1074 & 0,84 & HDZ-HNS & Manjinska \\
\hline
\end{tabular}

* MPK - minimalna pobjednička koalicija Izvor: autor.

Kad stabilnost hrvatskih koalicijskih vlada usporedimo s podacima o trajnosti vlada u zemljama srednje i istočne Europe koje su iznijeli Bergman, Ilonszki i Müller (2019b, str. 562), može se vidjeti da je prosječno trajanje vlada u deset novih demokracija članica Europske unije 547 dana, uz

${ }^{5}$ Mjera relativnog trajanja zahtijeva određen oprez u interpretaciji s obzirom na to da prikazuje stabilnijima kratkotrajne vlade koje su formirane tek nekoliko mjeseci prije redovitih izbora od vlada koje su uspjele preživjeti do toga vremena (više vidi u Bergman, Ilonszki \& Müller, 2019b, str. 562). Dobri primjeri koji ilustriraju taj interpretacijski problem vlade su Račan III i Kosor II. 
značajne varijacije među pojedinačnim slučajevima. ${ }^{6}$ Tako, s jedne strane, Mađarska značajno odstupa od prosjeka jer je njezinih 12 vlada prosječno trajalo oko 820 dana, dok su s druge strane Latvija i Rumunjska s više od 20 vlada koje su prosječno trajale manje od jedne godine. Hrvatska se savršeno uklapa u prosjek trajnosti vlada u regiji, bez značajnih odstupanja po bilo kojem pokazatelju, jer je njezinih 13 vlada u prosjeku trajalo 545 dana. Međutim, već sam podatak da vlade u srednjoj i istočnoj Europi traju u prosjeku oko godine i pol pokazuje razmjernu nestabilnost izvršne vlasti u novim demokracijama (Bergman, Ersson \& Hellström 2015, str. 349 , iznijeli su podatak da je prosječno trajanje vlada u istih deset zemalja do 2010. iznosilo 426 dana), a ta se činjenica dodatno pojačava kad usporedimo trajanje vlada u starim i novim demokracijama. Tako su u jednoj prijašnjoj studiji autori Müller i Strùm (2000, str. 5) iznijeli podatak da je prosječno trajanje vlada u 13 zapadnoeuropskih demokracija s čestim koalicijskim vladama oko dvije godine, odnosno 702 dana. Novija studija utvrdila je da vlade u 17 zapadnih demokracija traju u prosjeku 874 dana, promatrano od 1989. do 2010. (Bergman, Ersson \& Hellström, 2015). Uzimajući u obzir već spomenute varijacije u uzorcima zemalja i istraživačkim razdobljima, ipak se može zaključiti kako su vlade u novim demokracijama nestabilnije nego one na zapadu jer u prosjeku znatno kraće traju.

S obzirom na to da su koalicijske vlade u Hrvatskoj po svojim strukturnim obilježjima i razini stabilnosti slične koalicijskim vladama u drugim zemljama srednje i istočne Europe, u ovome radu nastoji se utvrditi može li se razmjerno kratko trajanje koalicijskih vlada u Hrvatskoj, do kojega dolazi zbog različitih sukoba među koalicijskim partnerima, objasniti karakteristikama koalicijskih sporazuma i načinima kako stranke upravljaju tim sukobima unutar koalicija. Polazeći od teze iznesene u uvodu, po kojoj su koalicijske vlade u Hrvatskoj nestabilne zbog nedovoljno razrađenih koalicijskih sporazuma i neučinkovitosti mehanizama rješavanja koalicijskih sukoba, u nastavku rada prvo se analiziraju koalicijski sporazumi s

${ }^{6}$ Vrlo je važno napomenuti da usporedbu trajanja vlada u Hrvatskoj s ostalim zemljama u regiji treba uzeti s određenom dozom opreza s obzirom na to da se razlikuju istraživačka razdoblja kojima su obuhvaćeni prikazani podaci. Tako su Bergman, Ilonszki i Müller prosječno trajanje vlada u deset zemalja računali zaključno s 2013. jer im je upravo te godine završilo projektno istraživanje u okviru kojega su prikupljali podatke, dok je u slučaju Hrvatske prosječno trajanje računato do sredine 2020. Unatoč toj nepodudarnosti smatram da se može napraviti određena razina pouzdane usporedbe, ponajprije zbog iste metodologije koja je upotrijebljena za izračun trajnosti vlada, ali i zbog velike oskudnosti takvih istraživanja u zemljama srednje i istočne Europe, pogotovo u slučaju Hrvatske. 
obzirom na veličinu i sadržaj koji je u njima zastupljen. Zatim se istražuju stvarni procesi koalicijskog upravljanja koji se događaju unutar „crne kutije", identificiranjem najčešćih sukoba i mehanizama s pomoću kojih se oni nastoje riješiti.

Analiza se temelji na 19 polustrukturiranih intervjua s članovima koalicijskih vlada od 2000. do 2020., od kojih je jedan premijer i 18 ministara. Nadalje, analizirani podaci prikupljeni su iz pet koalicijskih sporazuma i nekoliko dodatnih koalicijskih dokumenata, poput posebnih protokola i vladinih programa predstavljanih u Hrvatskom saboru pri glasanju o povjerenju. Kao važan izvor informacija poslužila je i arhivska građa dnevnih novina Večernji list i Vjesnik, kao i arhivske baze Vlade Republike Hrvatske i Hrvatskog sabora. ${ }^{7}$

\subsection{Analiza koalicijskih sporazuma}

U Tablici 2. prikazani su rezultati analize koalicijskih sporazuma koje su koalicijske stranke sklapale pri formiranju vlada od 2000. Za početak se može vidjeti da su stranke u Hrvatskoj sklonije sklapanju poslijeizbornih nego predizbornih sporazuma. Tako je lijevoliberalna koalicija šest stranaka pod vodstvom Ivice Račana najprije potpisala predizborni sporazum u rujnu 1999., a nakon što je pobijedila na izborima, i poslijeizborni koalicijski ugovor o formiranju vlade i vodstva Zastupničkog doma Sabora (vidi i Kasapović, 2005). Poslijeizborni sporazumi sklopljeni su i pri formiranju treće vlade Ive Sanadera nakon izbora 2007. i koalicijske vlade HDZ-a i Mosta pod premijerom Tihomirom Oreškovićem nakon izbora 2015. Milanovićeva koalicija četiriju stranaka sklopila je predizborni sporazum o zajedničkom izlasku na izbore 2011. koji je predvidio i zajedničko formiranje vlade, dok je Plenkovićeva treća vlada bila jedina koja je formirana na temelju međuizbornog sporazuma HDZ-a i HNS-a. ${ }^{8}$

${ }^{7}$ Svi podaci prikupljeni su u okviru međunarodnog projekta Party Government in Europe Database (PAGED) sa Sveučilišta UMEA (https://www.umu.se/en/research/projects/ party-government-in-europe-database/).

${ }^{8}$ Sanaderova prva vlada koju je, osim HDZ-a činio još i DC, formirana je na temelju koalicijskog sporazuma koji je sklopljen između dviju stranaka, ali taj je sporazum ostao nedostupan za potrebe ovog istraživanja. 
Tablica 2. Koalicijski sporazumi u Hrvatskoj

\begin{tabular}{|l|l|r|r|r|r|}
\hline $\begin{array}{c}\text { Koalicijska } \\
\text { vlada }\end{array}$ & \multicolumn{1}{|c|}{$\begin{array}{c}\text { Koalicijski } \\
\text { sporazum }\end{array}$} & $\begin{array}{c}\text { Veličina } \\
\text { (riječi) }\end{array}$ & $\begin{array}{c}\text { Proceduralna } \\
\text { pravila (\%) }\end{array}$ & $\begin{array}{c}\text { Podjela } \\
\text { resora (\%) }\end{array}$ & $\begin{array}{c}\text { Javne politi- } \\
\text { ke (\%) }\end{array}$ \\
\hline Račan I & PRED, POST & $1.235^{\circ}$ & 53.2 & 25.7 & 0.0 \\
\hline Račan II & PRED, POST & $1.235^{\circ}$ & 53.2 & 25.7 & 0.0 \\
\hline Račan III & PRED, POST & $1.235^{\circ}$ & 53.2 & 25.7 & 0.0 \\
\hline Sanader I & POST & N/AV & N/AV & N/AV & N/AV \\
\hline Sanader III & POST & $26.999^{3}$ & 3.7 & 0.9 & 91.5 \\
\hline Kosor I & POST & $26.999^{3}$ & 3.7 & 0.9 & 91.5 \\
\hline Kosor II & POST & $26.999^{3}$ & 3.7 & 0.9 & 91.5 \\
\hline Milanović & PRED & 674 & 100.0 & 0.0 & 0.0 \\
\hline Orešković & POST & 2.345 & 31.2 & 25.8 & 38.2 \\
\hline Plenković I & POST & $11.623^{1}$ & 0.0 & 0.0 & 100.0 \\
\hline Plenković III & MEĐU & 828 & 0.0 & 0.0 & 100.0 \\
\hline
\end{tabular}

PRED - predizborni; POST - poslijeizborni; MEĐU - međuizborni

- Isti koalicijski sporazum nastavio je vrijediti nakon kraja prve i druge Račanove vlade.

- Isti koalicijski sporazum nastavio je vrijediti nakon kraja Sanaderove treće i prve vlade Jadranke Kosor.

1/4 Odnosi se na Program Vlade predstavljen u Hrvatskom saboru pri glasanju o povjerenju. Izvor: autor.

U Tablici 2. također se može vidjeti da je prosječna duljina koalicijskih sporazuma oko 6.416 riječi, čime je Hrvatska usporediva s ostalim zemljama članicama Europske unije iz srednje i istočne Europe u kojima je prosječna duljina koalicijskih sporazuma 6.660 riječi (Bergman, Ilonszki \& Müller, 2019b, str. 548). Međutim, može se vidjeti da postoje znatne varijacije među pojedinačnim koalicijskim vladama, pa je tako najkraći koalicijski sporazum imala Milanovićeva vlada sa samo 674 riječi, dok je onaj najdulji imala Sanaderova treća vlada s gotovo 27.000 riječi, što ga svrstava među najobuhvatnije koalicijske sporazume sklopljene među strankama u srednjoj i istočnoj Europi. Ovdje valja izdvojiti i slučaj Plenkovićeve prve vlade koju su činili HDZ i Most, a koja nije formirana na temelju klasičnoga koalicijskog sporazuma, već su se dvije stranke usuglasile da će im osnova koalicijske suradnje biti program vlade predstavljen pri glasanju o povjerenju premijeru i ministrima. Stoga je u Tablici 2. i istaknuto da nije riječ o koalicijskom sporazumu, već koalicijskom dokumentu uobličenom u program rada vlade. ${ }^{9}$

${ }^{9}$ Jedan bivši ministar te vlade u intervjuu je istaknuo da su se vodstva HDZ-a i Mosta usuglasila da će se međusobni odnosi dviju stranaka u vladi regulirati mehanizmima 
Kad se pogleda raspodjela sadržaja koalicijskih sporazuma na tri tematska područja, također se može vidjeti da ne postoji ustaljen obrazac svojstven koalicijskim vladama na zapadu koje većinu sadržaja posvećuju programskim (policy) pitanjima. S jedne strane, može se vidjeti da se koalicijski sporazum „šestorke“ iz 2000. uglavnom bavio proceduralnim pravilima vezanima za koordinacijske aktivnosti unutar koalicije i mehanizme rješavanja međusobnih sukoba, kao i pitanjem raspodjele ministarstava i drugih funkcija na razini zamjenika ministara i tajnika ministarstava, dok o programskom aspektu dogovora nije bilo ni riječi. Slično je bilo is koalicijskim sporazumom Kukuriku koalicije iz 2011. koji je potpuno bio posvećen predizbornim proceduralnim pitanjima vezanima za utvrđivanje kandidacijskih lista i raspodjelu mjesta na njima u skladu s veličinom koalicijskih partnera. S druge pak strane imamo koalicijski sporazum na temelju kojeg je formirana koalicijska vlada HDZ-a, HSLS-a, HSS-a i SDSS-a pod vodstvom premijera Sanadera koji se može smatrati oglednim primjerom koalicijskoga dogovora, nastao po uzoru na zapadnoeuropske koalicijske sporazume. Riječ je o iznimno obuhvatnom sporazumu u kojemu je većina sadržaja (više od 90 posto) posvećena javnim politikama, dok se tek manji dio sadržaja odnosi na utvrđivanje mehanizama koordinacije i rješavanja sukoba te podjele resora. Sličan fokus na policy aspekt koalicijskog pregovaranja može se vidjeti i u koalicijskom sporazumu Plenkovićeve treće vlade, s obzirom na to da je cijeli sadržaj posvećen isključivo dogovoru HDZ-a i HNS-a o ključnim politikama kojima se vlada trebala baviti u preostalom dijelu mandata, poput obrazovanja, decentralizacije i jačanja gospodarstva. Konačno, u koalicijskom sporazumu HDZ-a i Mosta o formiranju Oreškovićeve vlade uravnoteženo su zastupljeni sadržaji svih triju tematskih područja jer je Most kao nova stranka na političkoj sceni manjak političkog iskustva nastojao kompenzirati sporazumom koji će obuhvatiti sve aspekte koalicijske suradnje.

Zaključno se može ustvrditi da su koalicijski sporazumi u Hrvatskoj, izuzev onoga iz 2008., razmjerno malog obuhvata i u njima se koalicijski partneri podjednako bave usuglašavanjem zajedničkih politika kao i proceduralnim pravilima kojima reguliraju međusobne odnose i mehanizme kojima planiraju rješavati potencijalne sukobe koji će se pojaviti tijekom mandata. Osim toga, uzimajući u obzir ograničenja vezana za mali uzorak od samo pet koalicijskih sporazuma, iz Tablice 2 . može se izvući i provizo-

dostupnima Zakonom o Vladi i Poslovnikom Vlade, dok je program vlade bio obuhvatni programski dokument u kojem su istaknuti ključni ciljevi i politike kojima se vlada trebala baviti tijekom mandata. 
ran zaključak o tome da su se lijeve koalicije koje sklapaju predizborne koalicijske sporazume sklonije u njima baviti proceduralnim pitanjima, dok su desne koalicije koje sporazume sklapaju nakon izbora sklonije u njima usuglašavati zajedničke politike. Dio objašnjenja zašto se lijeve koalicije u koalicijskim sporazumima uglavnom bave proceduralnim pitanjima, a desne policy pitanjima, zasigurno leži u različitoj ideološkoj strukturi suprotstavljenih koalicija. Tako su lijeve koalicijske vlade pod premijerima Račanom i Milanovićem bile ideološki homogenije i sastavljene od programski sličnih stranaka te su zbog toga bile manje usmjerene na usuglašavanje zajedničkih politika, a više na uređivanje međusobnih odnosa i raspodjelu funkcija u izvršnoj vlasti. S druge strane, desne koalicijske vlade Sanader III i Plenković III bile su sastavljene od ideološki i programski heterogenih stranaka koje su manje pozornosti posvećivale reguliranju proceduralnih pitanja, a više usuglašavanju zajedničkih programskih platformi.

\subsection{Analiza koalicijskog upravljanja i mehanizama rješavanja koalicijskih sukoba}

Već je spomenuto da su različiti sukobi među strankama u koaliciji najčešći razlog zbog kojega se prekida koalicijska suradnja i okončava mandat vlada. Stoga je važno utvrditi uz pomoć kojih mehanizama koalicijske stranke u Hrvatskoj nastoje upravljati unutarkoalicijskim sukobima i u kojoj su mjeri ti mehanizmi učinkoviti u rješavanju sukoba i očuvanju stabilnosti vlada. U Tablici 3. prikazani su razlozi kraja koalicijskih vlada, koji su podijeljeni na tehničke (nepolitičke) razloge okončanja mandata vlade određene ustavnim i zakonskim normama te diskrecijske (političke) određene dinamikom političkoga i stranačkog života. ${ }^{10} \mathrm{U}$ tablici se može vidjeti da sukobi među koalicijskim strankama vezani za politike i kadrovska pitanja najčešće dovode do prijevremenog okončanja koalicijske suradnje među partnerima na vlasti, što se dogodilo u šest slučajeva koalicijskih vlada.

Zapravo, tablica pokazuje da koalicijske vlade u Hrvatskoj okončavaju svoj život uglavnom na dva načina: a) redovitim parlamentarnim izborima i b) sukobima među koalicijskim strankama. Samo je jedna vlada završila svoj mandat zbog nekoga drugog razloga, a riječ je o Sanaderovoj trećoj vladi čiji je mandat završio kad je premijer samovoljno i bez objašnjenja podnio

10 Tehnički i diskrecijski razlozi okončanja vlada međusobno su isključivi, dok se diskrecijski unutar sebe mogu preklapati. 
ostavku. Dakle, stranke u koalicijskim vladama sklone su se često sukobljavati zbog nesuglasica proizišlih iz suprotstavljenih programskih ciljeva, ali i personalnih sukoba vezanih za osobe koje obnašaju dužnosti u vladi.

Tako je u Račanovim vladama (I i II) često dolazilo do sukoba između najveće koalicijske stranke SDP-a i njezinih partnera, najprije IDS-a zbog pitanja autonomije Istre, a poslije i HSLS-a u vezi sa suradnjom s Haškim sudom i problema vezanih za nuklearnu elektranu u Krškom. ${ }^{11} \mathrm{Na}$ sličan način okončana je i koalicijska suradnja HDZ-a i HSLS-a u prvoj vladi Jadranke Kosor jer je vodstvo HSLS-a donijelo formalnu odluku o tome da se povuče iz vlade zbog neslaganja s politikom HDZ-a. S druge strane, koalicijske vlade premijera Sanadera (I), Oreškovića i Plenkovića (I) okončane su ponajprije zbog personalnih sukoba čelnih osoba koalicijskih stranaka. Tako je osobni animozitet između premijera Sanadera i ministrice pravosuđa Vesne Škare-Ožbolt kulminirao 2005. njezinom smjenom i izlaskom DC-a iz koalicije, a Sanader je nastavio voditi manjinsku jednostranačku vladu uz potporu manjih stranaka u parlamentu, uključujući predstavnike nacionalnih manjina. ${ }^{12}$ Personalni sukobi dvaput su okončali i koalicijsku suradnju HDZ-a i Mosta. Najprije su osobni sukobi i animoziteti dvojice potpredsjednika vlade, Tomislava Karamarka i Bože Petrova, postali prevelik teret Oreškovićeve vlade koja je postala prva vlada kojoj je parlamentarna većina izglasala nepovjerenje. Zatim se u drugoj vladi pod vodstvom premijera Plenkovića razvio sukob HDZ-a i Mosta zbog pitanja povjerenja ministru financija u kontekstu afere „Agrokor“, što je rezultiralo premijerovom odlukom da smijeni Mostove ministre i tako raskine koalicijsku suradnju s Mostom. Nakon toga formirana je nova, ideološki „neprirodna" koalicijska vlada HDZ-a i HNS-a koja se uspjela održati do kraja ustavno definiranog mandata.

11 Djelomično je to bio i personalni sukob šefova koalicijskih stranaka oko nejasne pozicije predsjednika HSLS-a Dražena Budiše u okviru koalicijske suradnje.

12 Sukob Sanadera i Škare-Ožbolt bio je djelomično uvjetovan i suprotstavljenim preferencijama što se tiče politika koje je provodila Škare-Ožbolt kao ministrica pravosuđa, ponajprije u pitanjima reforme zemljišnih knjiga, pravosudne reforme i antikorupcijske politike. 
Tablica 3. Razlozi kraja koalicijskib vlada u Hrvatskoj 2000. - 2020.

\begin{tabular}{|c|c|c|c|c|c|c|c|c|c|c|}
\hline \multirow[t]{3}{*}{ Vlada } & \multicolumn{3}{|c|}{ Tehnički } & \multicolumn{6}{|c|}{ Diskrecijski } & \multirow[b]{2}{*}{ 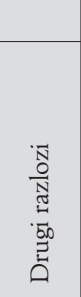 } \\
\hline & 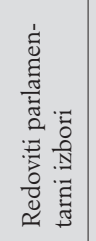 & 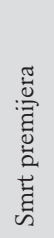 & 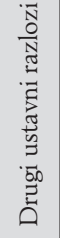 & 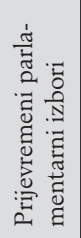 & 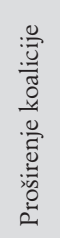 & 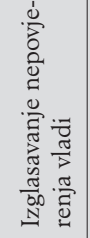 & \multicolumn{2}{|c|}{ 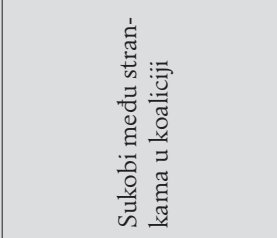 } & 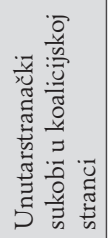 & \\
\hline & & & & & & & $\begin{array}{l}\text { Policy } \\
\text { sukobi }\end{array}$ & $\begin{array}{l}\text { Kadrovski } \\
\text { sukobi }\end{array}$ & & \\
\hline Račan I & & & & & & & IDS & & & \\
\hline Račan II & & & & & & & $\begin{array}{l}\text { SDP, } \\
\text { HSLS }\end{array}$ & $\begin{array}{l}\text { SDP, } \\
\text { HSLS }\end{array}$ & & \\
\hline Račan III & $X$ & & & & & & & & & \\
\hline Sanader I & & & & & & & HDZ, DC & HDZ, DC & & \\
\hline Sanader III & & & & & & & & & & $\mathrm{X}$ \\
\hline Kosor I & & & & & & & $\begin{array}{l}\text { HDZ, } \\
\text { HSLS }\end{array}$ & & & \\
\hline Kosor II & $\mathrm{X}$ & & & & & & & & & \\
\hline Milanović & $\mathrm{X}$ & & & & & & & & & \\
\hline Orešković & & & & & & $\mathrm{X}$ & $\begin{array}{l}\text { HDZ, } \\
\text { MOST }\end{array}$ & $\begin{array}{l}\text { HDZ, } \\
\text { MOST }\end{array}$ & & \\
\hline Plenković I & & & & & & & $\begin{array}{l}\text { HDZ, } \\
\text { MOST }\end{array}$ & $\begin{array}{l}\text { HDZ, } \\
\text { MOST }\end{array}$ & & \\
\hline Plenković III & $x$ & & & & & & & & & \\
\hline \multicolumn{11}{|c|}{$\begin{array}{l}\text { Izvor: autor. } \\
\text { S obzirom na česte sukobe među strankama u koalicijskim vladama koji } \\
\text { dovode do prijevremenog okončanja koalicijske suradnje i pada vlade, po- } \\
\text { stavlja se pitanje na koji način koalicijski partneri upravljaju tim sukobima } \\
\text { i kojim se mehanizmima koriste kako bi ih riješili te tako osigurali opsta- } \\
\text { nak koalicijske vlade. Tablica } 4 \text {. donosi pregled mehanizama rješavanja } \\
\text { sukoba kojima su se koristile koalicijske vlade u Hrvatskoj, a napravljena } \\
\text { je na temelju podataka prikupljenih analizom koalicijskih sporazuma i in- } \\
\text { tervjua s bivšim članovima vlada. Vidljivo je da su se sve koalicijske vla- } \\
\text { de koristile mehanizmima rješavanja sukoba koji se nalaze u unutrašnjoj } \\
\text { areni - uži kabinet vlade (IC) i vladine koordinacije (CaC). Međutim, } \\
\text { važno je istaknuti da ta tijela ne stvaraju same stranke tijekom koalicijskih } \\
\text { pregovora o formiranju vlade, već je riječ o visokoinstitucionaliziranim ti- }\end{array}$} \\
\hline
\end{tabular}


jelima čije su zadaće, nadležnosti i sastav definirani Zakonom o Vladi i Poslovnikom Vlade. Drugim riječima, sam zakonsko-pravni okvir rada vlade nudi koalicijskim strankama mehanizme s pomoću kojih mogu upravljati međusobnim odnosima i rješavati unutrašnje sukobe na svakodnevnoj razini. U tablici se može vidjeti da se koalicijski partneri koriste upravo tim institucionaliziranim mehanizmima za rješavanje najčešćih sukoba, odnosno onih sukoba koji su obično niska intenziteta i u vezi s kojima se stranke u koaliciji mogu razmjerno lako usuglasiti.

Tablica 4. Mehanizmi rješavanja koalicijskih sukoba

\begin{tabular}{|l|l|c|c|}
\hline Koalicijska vlada & $\begin{array}{c}\text { Mehanizmi rješava- } \\
\text { nja sukoba (svi) }\end{array}$ & $\begin{array}{c}\text { Mehanizmi rješava- } \\
\text { nja najčešćih sukoba }\end{array}$ & $\begin{array}{c}\text { Mehanizmi rješava- } \\
\text { nja najtežih sukoba }\end{array}$ \\
\hline Račan I & IC, CaC, PS, Parl & IC, PS & PS \\
\hline Račan II & IC, CaC, PS, Parl & IC, PS & PS \\
\hline Račan III & IC, CaC, PS, Parl & IC, PS & PS \\
\hline Sanader I & PS & PS & PS \\
\hline Sanader III & IC, CaC, CoC, PS & IC, CaC, PS & PS \\
\hline Kosor I & IC, CaC, CoC, PS & IC, CaC, PS & PS \\
\hline Kosor II & IC, CaC, CoC, PS & IC, CaC, PS & PS \\
\hline Milanović & IC, CaC, PS, PCa & IC & IC, PS \\
\hline Orešković & IC, CaC, PS, CoC & PS & PS \\
\hline Plenković I & IC, CaC, PS & IC, CaC & CoC, PS \\
\hline Plenković III & IC, CaC, CoC, PS & IC, CoC & \\
\hline
\end{tabular}

IC - uži kabinet vlade / Inner cabinet; CaC - vladini odbori / Cabinet committees; Parl - odbor parlamentarnih vođa / Parliamentary leaders; PS - stranački summiti / Party summits; CoC koalicijski odbori / Coalition committees; PC - parlamentarni odbori / Parliamentary committees Izvor: autor.

S druge strane, iz koalicijskih sporazuma može se vidjeti koja su tijela formirale same stranke kako bi osigurale usklađivanje koalicijskoga djelovanja i rješavanje međusobnih sporova. U koalicijskom sporazumu „šestorke“ iz siječnja 2000. navedeno je kako će za rješavanje budućih sporova biti nadležna Koordinacija koalicije koju čine predsjednik vlade i predsjednici stranaka u koaliciji (PS), dok se za usklađivanje rada u parlamentu formira Koordinacija klubova koju će činiti predsjednici klubova zastupnika koalicijskih stranaka (Parl). Koalicijskim sporazumom HDZ-a, HSS-a i HSLS-a iz 2008. predviđeno je da sve odluke koje se prihvaćaju u 
vladi i parlamentu moraju biti usklađene unutar koalicije, pa se s tom svrhom formiraju posebna koalicijska tijela koja trebaju osigurati koordinaciju među koalicijskim strankama. Riječ je o a) koordinaciji predsjednika stranaka (PS) kao najvišem koalicijskom tijelu koje bi trebalo donositi konačne odluke o svim prijepornim pitanjima oko kojih se ne može ostvariti suglasje na nižim koalicijskim razinama i b) međustranačkoj koordinaciji gdje su na koalicijskim sastancima sudjelovali predstavnici koalicijskih partnera ovisno o temi o kojoj se raspravljalo, a činila su je šira predsjedništva stranaka (CoC). Nadalje, sporazumom Domoljubne koalicije predvođene HDZ-om i Mosta iz siječnja 2016. uspostavljeno je Vijeće za suradnju (CoC) koje je činilo najviše 14 predstavnika dvaju koalicijskih partnera, uključujući predsjednike klubova zastupnika HDZ-a i Mosta, a trebalo se baviti koordinacijom zajedničkoga djelovanja, rješavanjem spornih pitanja i predlaganjem kadrovskih rješenja. Konačno, potrebno je istaknuti da u koalicijskim sporazumima koji su sklopljeni za potrebe formiranja Milanovićeve vlade i Plenkovićeve treće vlade nije bilo spomena posebnih koalicijskih tijela.

Međutim, kad se nastoji utvrditi u kojoj su mjeri ta posebno formirana koalicijska tijela bila korištena u stvarnoj praksi koalicijskog upravljanja, tada se iz intervjua s bivšim članovima vlada može izvući jasan zaključak da su ta tijela u osnovi imala marginalnu ulogu i uglavnom su se pokazala neučinkovitima u rješavanju najtežih sukoba među strankama u koalicijama, odnosno onih sukoba koji najčešće dovode do pada vlade. U Tablici 4. može se vidjeti da su beziznimno sve koalicijske vlade najteže sukobe koji su izbijali među strankama u koaliciji rješavale na sastancima šefova koalicijskih stranaka (PS), uključujući i one vlade koje u sporazumima nisu spominjale takva tijela (Orešković), kao i one koje koalicijskim sporazumima nisu predvidjele formiranje bilo kakvih koalicijskih tijela (Milanović, Plenković I i Plenković III).

Gotovo svi intervjuirani članovi koalicijskih vlada identificirali su sastanke stranačkih vođa kao najvažnije vanjske mehanizme rješavanja najtežih međustranačkih sukoba u Hrvatskoj, odnosno postoji suglasje o tome da se o gotovo svim najvažnijim aspektima koalicijskog upravljanja odlučuje upravo u usku krugu čelnika koalicijskih stranaka. Kad se procjenjuju njihova struktura i priroda, iz podataka prikupljenih intervjuima može se zaključiti da je riječ o vrlo usku krugu vođa koalicijskih stranaka s premijerom kao središnjim akterom, a mogu biti uspostavljeni kao stalni ili ad hoc mehanizmi rješavanja sukoba. Po prirodi ih karakterizira znatna razina personalnog i neformalnog načina odlučivanja, s vrlo ograničenom mogućnošću da se nametnu određeni oblici javne ili unutarstranačke kontrole. Tako su se tijekom Račanove prve vlade šestorica stranačkih predsjednika redovito 
sastajala kako bi raspravila i razriješila sva prijeporna pitanja unutar koalicije. Međutim, prema intervjuiranim dužnosnicima, taj je mehanizam funkcionirao bez ikakvih ustanovljenih pravila i procedura te je uglavnom ovisio o (dobrim) osobnim odnosima među stranačkim vođama, što se pokazalo i kao glavni izvor terminalnih sukoba unutar koalicije. Na sličan su način funkcionirale i koalicijske vlade pod vodstvom Sanadera (I i III) i Milanovića. U tim su slučajevima premijeri Sanader i Milanović preferirali rješavati koalicijske sporove neformalnim bilateralnim sastancima s drugim vođama koalicijskih stranaka, obično tijekom privatnih ručkova ili u nekome drugom nekonvencionalnom okruženju. ${ }^{13} \mathrm{U}$ slučaju Oreškovićeve vlade glavna dinamika koalicijskog odlučivanja stvorila se između čelnika HDZ-a i Mosta, Karamarka i Petrova, koji su ujedno obnašali dužnost potpredsjednika vlade, dok je sam premijer Orešković, na sličan način kao i glavno koalicijsko tijelo Vijeće za suradnju, bio marginaliziran u rješavanju sukoba. Upravo su narušeni osobni odnosi i animoziteti između dvojice stranačkih vođa ugrozili stabilnost vlade i na kraju doveli do njezina pada, dok je Orešković na samom kraju neuspješno pokušao posredovati da bi se taj spor riješio i izbjegao raspad koalicije. Plenkovićeve vlade (I i III) slijedile su sličan obrazac koalicijskog upravljanja, što je pogotovo bilo vidljivo u koalicijskoj vladi HDZ-a i Mosta kad su dvojica stranačkih vođa Plenković i Petrov bilateralnim sastancima nastojali usuglasiti najteŽe točke prijepora unutar koalicije. Oni su na taj način u posljednjoj fazi nastojali riješiti i terminalni sukob koji je izbio između dviju stranaka u vezi s izglasavanjem nepovjerenja ministru financija, ali se pokazalo da je to bila nepremostiva točka razdora koja je dovela do konačnog pada vlade.

\section{Rasprava i zaključak}

S obzirom na to da su u posljednjih dvadeset godina koalicijske vlade postale norma u hrvatskome stranačkom i političkom sustavu, u ovome radu bilo je važno utvrditi razine stabilnosti vlada i analizirati utjecaj koalicij-

13 Sanader je bio percipiran kao vrlo autoritaran predsjednik vlade koji je želio biti uključen u donošenje svih važnijih odluka na razini vlade i pojedinačnih ministarstava (Nikić Čakar, 2013). Po riječima jednoga intervjuiranog člana vlade, nikad se nije donijela odluka koja bi bila suprotna Sanaderovu stavu i mišljenju, a u odnosima s pojedinačnim ministrima i čelnicima koalicijskih stranaka njegovao je pomalo tiranski stil. S druge strane, jedan intervjuirani ministar u Milanovićevoj vladi istaknuo je da se o najvažnijim pitanjima odlučivalo na koordinaciji čelnika stranaka tijekom „ručkića“, što pokazuje visoku razinu neformalnosti u procesu koalicijskog upravljanja. 
skih sporazuma na njihovu stabilnost i duljinu trajanja. Analiza je pokazala da je Hrvatska slična novim demokracijama u srednjoj i istočnoj Europi što se tiče veće nestabilnosti vladinih koalicija, koje u prosjeku traju gotovo dvostruko kraće nego koalicijske vlade u zapadnoj Europi. Polazeći od recentnih istraživanja koja su upozorila na to da formuliranje obuhvatnih koalicijskih sporazuma može imati povoljan učinak na stabilnost koalicijskih vlada i dulje trajanje njihova mandata, ovaj rad počeo je od teze da se relativno kratko trajanje koalicijskih vlada u Hrvatskoj može objasniti upravo nedovoljno obuhvatnim koalicijskim sporazumima i neučinkovitim mehanizmima prevencije i rješavanja sukoba koji su u njih ugrađeni. Rezultati istraživanja doveli su do nekoliko zanimljivih zaključaka vezanih za stanje koalicijske politike u Hrvatskoj.

Prvo, analizom veličine i sadržaja koalicijskih sporazuma utvrdilo se da su političke stranke udružene u koalicije sklone sastavljati sporazume kojima nastoje regulirati međusobne odnose u vladi, ali su ti koalicijski sporazumi, uz iznimku jednoga, nedovoljno obuhvatni. Suprotno iskustvima zapadnoeuropskih i većine istočnoeuropskih zemalja, u slučaju Hrvatske vidljivo je da ne postoji neki linearni trend povećanja opsega koalicijskih sporazuma ni detaljnije razrade mehanizama prevencije i rješavanja sukoba među koalicijskim strankama, što upozorava na to da među političkim strankama u Hrvatskoj još nije izgrađena institucionalizirana svijest o tome da koalicijski sporazumi mogu imati ključnu ulogu u izgradnji stabilnih koalicijskih vlada. Drugim riječima, koalicijski sporazumi ne nude političkim strankama udruženima u vladine koalicije dovoljno razrađene instrumente uz pomoć kojih one mogu upravljati koalicijskim sukobima i na taj način amortizirati neposredne učinke najtežih prijepora koji prijete okončanjem njihove suradnje.

Drugi zaključak proizišao iz analize pokazuje da su upravo sukobi među strankama u koaliciji najčešći razlog prijevremenog okončanja koalicijske suradnje i završetka mandata vlade. Unutarkoalicijski sukobi manifestiraju se u obliku programskih i kadrovskih sporova među strankama koji su u podjednakoj mjeri dovodili do pada koalicijskih vlada u Hrvatskoj. Čak se i one vlade koje su imale na raspolaganju određene mehanizme rješavanja sukoba ugrađene u koalicijske sporazume (Račan, Kosor i Orešković) nisu mogle nositi sa stvarnom dinamikom koalicijskog upravljanja, koja je stranke u koaliciji neprestano dovodila u konfliktne situacije na koje one nisu imale adekvatan formalan odgovor.

Treće, upravo zbog nedovoljno razrađenih i formaliziranih instrumenata za upravljanje najtežim koalicijskim sukobima stranke udružene u koalici- 
je obično pribjegavaju ad hoc mehanizmu neformalnoga i vrlo personaliziranog odlučivanja koji se izgrađuje u malom gremiju čelnika koalicijskih stranaka. Takva tijela ne mogu izgraditi i održavati stabilne i trajne veze povjerenja između koalicijskih partnera, pogotovo kad je riječ o ideološki i programski heterogenoj koaliciji, a često su i sama opterećena narušenim osobnim odnosima, animozitetima i rivalstvima koji se stvaraju među stranačkim vođama. Podaci prikupljeni intervjuima s članovima vlada upućuju na to da je takav mehanizam koalicijskog upravljanja vrlo dvojben ne samo iz perspektive demokratske legitimacije i mogućnosti uspostave javnog nadzora već i u pogledu arbitrarnosti odlučivanja koja proizlazi iz njega. Zapravo, za sastanke koalicijskih vođa obično se veže negativna slika po kojoj se oni percipiraju kao svojevrsna parapolitička tijela koja se nalaze izvan konvencionalne političke arene i u kojima se donose odluke koje se smatraju rezultatom političke trgovine.

Konačno, uzimajući u obzir nedavni izborni uspjeh novih stranaka koje ne samo da su u znatnoj mjeri destabilizirale stranački sustav već i promijenile obrasce koalicijskog pregovaranja i formiranja vlada, može se očekivati da se u budućnosti neće znatnije promijeniti takvi ustaljeni obrasci koalicijske politike i koalicijskog upravljanja. Recentno iskustvo s dvjema koalicijskim vladama u kojima je sudjelovao Most kao nova platforma u hrvatskoj politici pokazalo je da nove stranke unose veliku razinu nepredvidivosti i neizvjesnosti $u$ arenu koalicijskog upravljanja te zbog svoga ponašanja postaju važan čimbenik dodatne nestabilnosti koalicijskih vlada. S obzirom na dinamiku razvoja stranačkog sustava u Hrvatskoj, možemo pretpostaviti da će nove stranke i političke platforme, koje kucaju na vrata koalicijske politike, zbog manjka političkog iskustva prihvatiti uhodanu koalicijsku igru koju će im nametnuti etablirane stranke, a koja je obilježena visokom razinom personalnih odnosa i neformalnog odlučivanja.

\section{Literatura}

Andeweg, R. B., \& Timmermans, A. (2008). Conflict management in coalition governments. U K. Strùm, W. C. Müller, \& T. Bergman (eds.), Cabinets and coalition bargaining: the democratic life cycle in Western Europe (str. 269-300). Oxford, UK: Oxford University Press, https://doi.org/10.1177/13540688110 170030803.

Bergman, T., Ersson, S., \& Hellström, J. (2015). Government formation and breakdown in Western and Central Eastern Europe. Comparative European Politics, 13(3), 345-375, https://doi.org/10.1057/cep.2013.27. 
Bergman, T., Ilonszki, G., \& Müller, W. C. (eds.) (2019a). Coalition governance in Central Eastern Europe. Oxford, UK: Oxford University Press, https://doi. org/10.1093/oso/9780198844372.001.0001.

Bergman, T., Ilonszki, G., \& Müller, W. C. (eds.) (2019b). The coalition life-cycle in Central Eastern Europe. U T. Bergman, G. Ilonszki, \& W. C. Müller (eds.), Coalition governance in Central Eastern Europe (str. 522576). Oxford, UK: Oxford University Press, https://doi.org/10.1093/ oso/9780198844372.003.0013.

Blondel, J., \& Müller-Rommel, F. (eds.) (2001). Cabinets in Eastern Europe. Basingstoke: Palgrave Macmillan.

Blondel, J., Müller-Rommel, F., \& Malova, D. (2007). Governing new European democracies. Hampshire \& New York: Palgrave Macmillan, https://doi. org/10.1057/9780230800595.

Bowler, S., Bräuninger, T., Debus, M., \& Indridason, I. H. (2016). Let's just agree to disagree: dispute resolution mechanisms in coalition agreements. The Journal of Politics, 78(4), 1264-1278, https://doi.org/10.1086/686805.

Cioffi-Revilla, C. (1984). The political reliability of Italian Governments: An Exponential Survival Model. American Political Science Review, 78, 318-337, https://doi.org/10.2307/1963367.

Damgaard, E. (2008). Cabinet termination. U W. C. Müller, \& K. Strùm (eds.), Coalition governments in Western Europe (str. 301-326). Oxford, UK: Oxford University Press.

Grofman, B., \& van Roozendaal, P. (1997). Modelling durability and termination. British Journal of Political Science, 27(3), 419-51, https://doi.org/10.1017/ s0007123497000203.

Grotz, F., \& Weber, T. (2012). Party systems and government stability in Central and Eastern Europe. World Politics, 64(4), 699-740, https://doi.org/10.1017/ s0043887112000196.

Indridason, I. H., \& Kristinsson, G. H. (2013). Making words count: coalition agreements and cabinet management. European Journal of Political Research, 52(6), 822-846, https://doi.org/10.1111/1475-6765.12022.

Kasapović, M. (2005). Koalicijske vlade u Hrvatskoj: prva iskustva u komparativnoj perspektivi. U G. Čular (ur.), Izbori i konsolidacija demokracije u Hrvatskoj (str. 181-209). Zagreb, Hrvatska: Fakultet političkih znanosti.

King, G., Alt, J., Burns, N., \& Laver, M. (1990). A unified model of cabinet dissolution in parliamentary democracies. American Journal of Political Science, 34(3), 846-871, https://doi.org/10.2307/2111401.

Krašovec, A., \& Krpič, T. (2019). Naj ostanem ali grem? Vladne koalicije in koalicijski sporazumi v Sloveniji med letom 1990 in 2018. Teorija in praksa, 56(1), 229-246.

Krauss, S. (2018). Stability through control? The influence of coalition agreements on the stability of coalition cabinets. West European Politics, 41(6), 1282-1304, https://doi.org/10.1080/01402382.2018.1453596. 
Laver, M. (1974). Dynamic factors in government coalition formation. European Journal of Political Research, 2, 259-270, https://doi. org/10.1111/j.1475-6765.1974.tb00753.x.

Laver, M., \& Shepsle, K. A. (1990). Coalitions and cabinet government. American Political Science Review, 84(3), 873-890, https://doi.org/10.2307/1962770.

Laver, M., \& Shepsle, K. A. (1996). Making and breaking governments: cabinets and legislatures in parliamentary democracies. Cambridge, UK: Cambridge University Press, https://doi.org/10.1007/978-3-531-90400-9_61.

Lupia, A., \& Strùm, K. (1995). Coalition termination and the strategic timing of parliamentary elections. American Political Science Review, 89(3), 648-665, https://doi.org/10.2307/2082980.

Moury, C. (2013). Coalition government and party mandate: bow coalition agreements constrain ministerial action. London, UK: Routledge, https://doi. org/10.4324/9780203084045.

Moury, C., \& Timmermans, A. (2013). Inter-Party conflict management in coalition governments: analysing the role of coalition agreements in Belgium, Germany, Italy and the Netherlands. Politics and Governance, 1(2), 117-131, https://doi.org/10.17645/pag.v1i2.94.

Müller, W. C., Bergman, T., \& Ilonszki, G. (2019). Extending the coalition Lifecycle approach to Central Eastern Europe - an introduction. U T. Bergman, G. Ilonszki, \& W. C. Müller (eds.), Coalition governance in Central Eastern Europe (str. 1-59). Oxford, UK: Oxford University Press, https://doi. org/10.1093/oso/9780198844372.003.0001.

Müller, W. C., Bergman, T., \& Strùm, K. (2008). Coalition theory and cabinet governance: an introduction. U K. Strùm, W. C. Müller, \& T. Bergman (eds.), Cabinets and coalition bargaining: the democratic life cycle in Western Europe (str. 1-50). Oxford, UK: Oxford University Press, https://doi.org/10.1177/13540 688110170030803.

Müller, W. C., \& Strùm, K. (eds.) (2000). Coalition governments in Western Europe. Oxford, UK: Oxford University Press.

Müller, W. C., \& Strùm, K. (2008). Coalition agreements and cabinet governance. U K. Strùm, W. C. Müller, \& T. Bergman (eds.). Cabinets and coalition bargaining: the democratic life cycle in Western Europe (str. 159-200). Oxford, UK: Oxford University Press, https://doi.org/10.1177/135406881101700308 03.

Müller-Rommel, F. (2005). Types of cabinet durability in Central Eastern Europe. Preuzeto s https://escholarship.org/uc/item/8cv4134w.

Nikić Čakar, D. (2013). Prezidencijalizacija političkih stranaka. Zagreb, Hrvatska: Fakultet političkih znanosti.

Nikolenyi, C. (2004). Cabinet stability in Post-Communist Central Europe. Party Politics, 10(2), 123-150, https://doi.org/10.1177/1354068804040497.

Saalfeld, T. (2008). Institutions, chance and choices: the dynamics of cabinet survival. U K. Strùm, W. C. Müller, \& T. Bergman (eds.), Cabinets and coalition bargaining: the democratic life cycle in Western Europe (str. 327-368). Oxford, 
UK: Oxford University Press, https://doi.org/10.1177/135406881101700308 03.

Saalfeld, T. (2009). Intra-party conflict and cabinet survival in 17 West European democracies, 1945-1999. U D. Giannetti, \& K. Benoit (eds.), Intra-party politics and coalition governments (str. 169-186). London and New York: Routledge, https://doi.org/10.4324/9780203889220.

Somer-Topcu, Z., \& Williams, L. K. (2008). Survival of the fittest? Cabinet duration in postcommunist Europe. Comparative Politics, 40(3), 313-329, https:// doi.org/10.5129/001041508x12911362383075.

Strùm, K., Browne, E. C., Frendreis, J. P., \& Gleiber, D. W. (1988). Contending models of cabinet stability. American Political Science Review, 82(3), 930-941, https://doi.org/10.2307/1962499.

Strùm, K., \& Müller, W. C. (1999). The keys to togetherness: coalition agreements in parliamentary democracies. Journal of Legislative Studies, 5, 255-282.

Strùm, K., Müller, W. C., \& Bergman, T. (eds.) (2008). Cabinets and coalition bargaining: the democratic life cycle in Western Europe. Oxford, UK: Oxford University Press, https://doi.org/10.1177/13540688110170030803.

Timmermans, A. (2006). Standing apart and sitting together: Enforcing coalition agreements in multiparty systems. European Journal of Political Research, 45, 263-283, https://doi.org/10.1111/j.1475-6765.2006.00298.x.

Timmermans, A., \& Moury, C. (2006). Coalition governance in Belgium and the Netherlands: rising government stability against all electoral odds. Acta Politica, 41(4), 389-407, https://doi.org/10.1057/palgrave.ap.5500139.

Warwick, P. (1994). Government survival in parliamentary democracies. Cambridge, UK: Cambridge University Press. 


\title{
GOVERNMENT STABILITY AND COALITION CONFLICT MANAGEMENT IN CROATIA
}

\begin{abstract}
Summary
The aim of this paper is to explore the stability of coalition governments in Croatia in the period 2000-2020, starting with the premise that cabinet instability is influenced by the limited scope of coalition agreements and ineffective conflict resolution mechanisms. The paper first analyses coalition agreements with regard to their scope and content, and goes on to explore the actual processes of coalition governance that occur within the "black box" by identifying the most common conflicts and the mechanisms which are used to resolve these. The analysis uses original empirical data collected through interviews with former members of coalition governments, as well as coalition agreements, government programmes, the archives of two daily newspapers, and archival databases of the government and parliament. Research results have led to the main conclusion that due to insufficiently developed and formalised coalition agreements, coalition parties are not successful at managing coalition conflicts, so they resort to the ad boc mechanism of informal and highly personalised decision-making which is generated by a small group of coalition leaders.
\end{abstract}

Keywords: coalition governments stability, coalition agreements, inter-party conflicts, coalition governance, Croatia 